\title{
Patiëntenvoorlichting
}

\section{PV 31 Cheilitis granulomatosa}

Cheilitis chranulomatosa is een chronische ontstekingsachtige aandoening van de lippen. Het is een relatief zeldzame aandoening, die vooral op jongvolwassen en middelbare leeftijd voorkomt. De oorzaak is onbekend. Het kan gaan om een zwelling van de gehele onder- of bovenlip. Gelijktijdig voorkomen is een zeldzaamheid. Een enkele maal breidt de ontsteking zich uit tot aan het tandvlees van de voortanden. Bij een enkele patiënt blijkt tevens sprake van een gegroefde tong en een in het verleden doorgemaakte tijdelijke, enkelzijdige verlamming van de aangezichtszenuw. Deze drie symptomen (cheilitis granulomatosa, gegroefde tong en tijdelijke aangezichtsverlamming) zijn bekend onder de benaming "syndroom van Melkersson-Rosenthal”. Net zo zeldzaam als voornoemd syndroom is, is de kans dat cheilitis granulomatosa een uiting is van de ziekte van Crohn, een ontstekingsachtige aandoening van de darm.

De lipzwelling doet zich aanvankelijk voor als een soms pijnlijke, op- en afgaande aandoening, die uiteindelijk in min of meer permanente vorm blijft bestaan. Hoewel de ziektegeschiedenis en de manier waarop de lipzwelling zich presenteert erg kenmerkend zijn voor de afwijking, wordt in veel gevallen toch een weefselstukje verwijderd voor onderzoek door de patholoog. Er is helaas geen goede behandeling voor cheilitis granulomatosa. Soms verdwijnt de afwijking spontaan binnen enkele maanden. Het enkele malen per dag insmeren van de zwelling met een hormoonhoudende zalf geeft bij sommige patiënten enige verbetering. In extreme situaties wordt wel eens tot chirurgische correctie overgegaan. Het cosmetische resultaat van een dergelijke ingreep is niet goed te voorspellen.

\section{Wat kunt u zelf doen?}

U kunt bij cheilitis granulomatosa eigenlijk zelf niets doen.
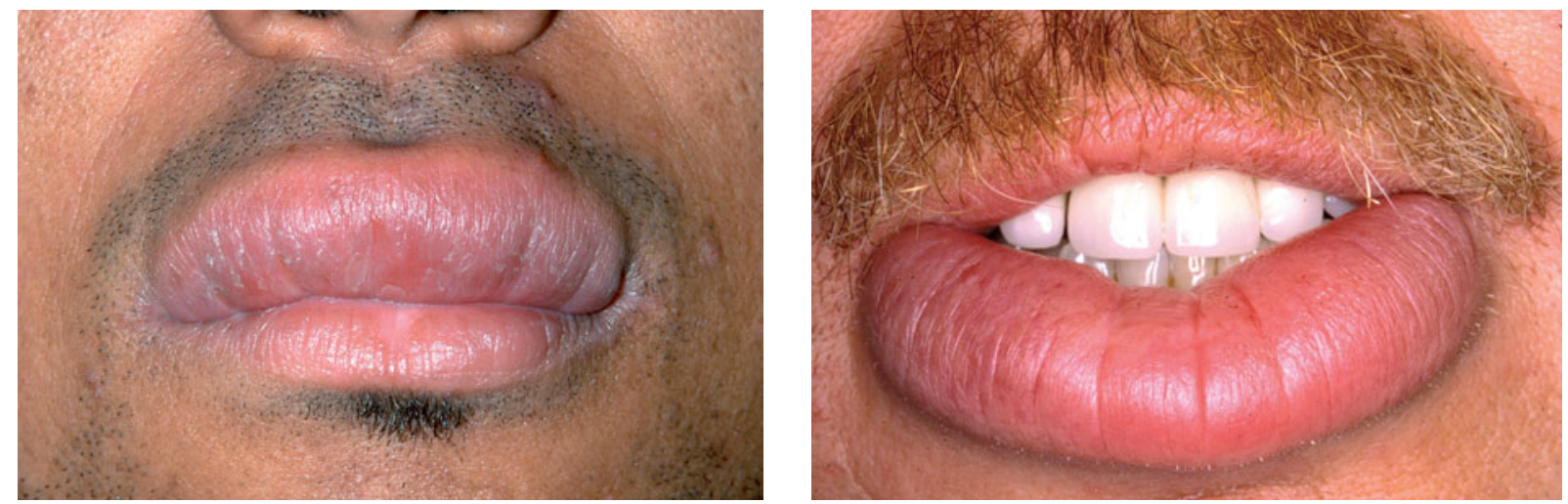